\title{
Compensation and Socio-Economic Status of Borrowers in Foreclosure: Evidence from Swedish Micro-data
}

\section{Lundholm ${ }^{1}$}

Received: 22 April 2020 / Accepted: 24 November 2020/ Published online: 29 December 2020

(C) The Author(s) 2020

\begin{abstract}
Proper compensation during foreclosure is essential to any effort to protect borrowers as consumers. However, the effectiveness of consumer protection and other safety nets during foreclosure has been debated within academia. This study contributes to this debate by exploring socio-economic group differences related to the compensatory potential of foreclosure proceedings. It employs micro-level data on foreclosure auctions in Sweden from 2000 to 2014. The results indicate that there is a correlation between high socio-economic status and a greater potential for compensation and that this is likely not explained by appraiser bias. This article discusses these empirical findings in terms of the need for strict consumer protection regulation and other safety nets, such as alternative mortgage products or debt relief, to ensure that there is a potential for compensation for all borrowers in foreclosure, regardless of socio-economic status.
\end{abstract}

Keywords Consumer protection · Compensation · Socio-economic status · Mortgage · Foreclosure

As you go to the bank to sign the mortgage papers for your new house, you probably do not think about the dense consumer protection regulation that has been safeguarding you up to this point. And you certainly do not worry about how your future interests as an indebted homeowner are protected and what would happen in the event of economic hardship. But at the back of your mind, you very likely think that you will be well compensated when you decide to sell the house. In this study, I turn this line of reasoning upside down by considering consumer protection and compensation from the perspective that you are forced to leave the house because you cannot pay the mortgage instalments and interest, i.e., foreclosure.

Foreclosure as a legal institution aims to terminate the mortgage contract after default and provide the lender with compensation. However, in the Swedish setting, there are not many legal guarantees that secure the compensatory potential of foreclosure and we know little about

M. Lundholm

mikael.lundholm@soclaw.lu.se

1 Sociology of Law Department, Lund University, Box 42, 22100 Lund, Sweden 
if and how compensation varies. This makes compensation during foreclosure a vital issue to study and understand in order to consider the borrower's position as a consumer and need for protection. Furthermore, the consumer protection perspective on foreclosure is relatively new and unexplored. This study addresses these knowledge gaps by investigating the potential for compensation on micro-level data of borrowers in foreclosure in Sweden from 2000 to 2014 in two steps. Firstly, the association between this compensatory potential and the borrower's socio-economic status is examined to determine whether there are group differences. Group differences imply that a specific socio-economic status - low or high — is associated with a specific potential for compensation-lesser or greater. Secondly, one potential explanation of group differences - appraiser bias during the foreclosure auction process - is assessed. This allows me to answer the following research questions: How does the compensatory potential of foreclosure vary for borrowers of different socio-economic status? How can socio-economic group differences be explained?

The main contribution of this empirical study is twofold. It aims to inform the academic debate on the need for consumer status and protection for mortgage borrowers during foreclosure. It also aims to stimulate a policy discussion about which remedies are appropriate for this group of consumers. Furthermore, this study contributes with an empirical description of the Swedish case of foreclosure. On a theoretical level, it provides an empirical application of Donald Black's predictions about the behaviour of law and compensation $(1976,1987)$.

Bar-Gill and Ben-Shahar (2013) suggest that strategies for consumer protection regulation include mandatory provisions that target both entry into and the running course of the contract. I delimit consumer protection policy as regulation that sets obligatory and enforceable standards for all aspects of the contractual relationship between the lender and the borrower, including the pre-contractual — what happens before signing? — and the post-contractualwhat happens after termination? — stages. Consumer protection during access to credit have been recognized and implemented in regulation for some time now, as exemplified on the EU level by the Consumer Credit Directive 2008 (CCD) and the more recent Mortgage Credit Directive 2014 (MCD) (De Gioia-Carabellese 2018). However, the extension of consumer protection to encompass the entire credit lifecycle has only recently been the subject of academic and regulatory attention (Nield 2015; Ramsay and Williams 2020; Whitehouse 2015). Thus, mortgage borrowers in economic hardship have been, and still are, largely left to fend for themselves even if there are also other safety nets beyond consumer protection policies, such as debt relief (Ramsay 2015) and welfare policies (Ford and Quilgars 2001). What such safety nets have in common is that they may intervene with other stakeholders beyond the lender and the borrower, such as the state or other creditors.

Compensation entails payment for the lender and avoidance of arrears but also a return on the housing investment for the borrower. However, one way to consider compensation, from a socio-legal perspective, is as a variable measure of law's potential to compensate (Black 1976, 1987). ${ }^{1}$ The focus is then not on the consequences of law, but rather on how law itself behaves - its operations as law is activated by the contract parties and other stakeholders regarding various aspects of and related to the credit contract-in order to provide the

\footnotetext{
${ }^{1}$ In his 1976 book The Behavior of Law, American sociologist Donald Black proposes that law's operations-its behaviour - should be measured along two separate axes: quantity (more or less law) and style (their logic, for example, compensation). How law operates in a specific case is explained by the social properties of the case along multiple aspects which reference its location in society (for example, the distribution of social control) and its direction with regard to the relative positions of the stakeholders (for example, their relational distance or differences in wealth).
} 
stakeholders with the potential for compensation. This compensatory potential is observable and variable in a given case between a lender and a borrower, which means that it may be lesser or greater depending on how law is activated to secure eventual payment.

The potential for compensation is vital for any effort to protect borrowers in foreclosure as consumers. If there are group differences with regard to this compensatory potential, some borrowers are exposed to a greater risk of arrears. Socio-economic group differences related to the compensatory potential may be explained by many factors. Bias during foreclosure proceedings is one such explanatory factor. Bias involves preferential treatment of subgroups of borrowers based on socio-economic status. Lenders may treat borrowers differently when negotiating about alternative solutions to forced sale of the property. The enforcement authorities may discriminate against borrowers, for example, when prioritizing cases, appraising the real property's market value, or accepting bids at the foreclosure auction. Other factors that may explain socio-economic group differences are external to the foreclosure proceedings. Such factors include the price for the property upon purchase by the borrower (high-status borrowers are possibly making better deals) and the property's condition in terms of maintenance and investment during ownership (high-status borrowers are possibly taking better care of their properties). Additionally, micro- and macro-economic trends both before and during foreclosure, such as residing in an area with stagnant house prices or being affected by a global financial crisis, may be relevant if they are related to socio-economic status. It is an empirical question which factors explain group differences in the potential for compensation during foreclosure. These factors are important when considering which remedies are appropriate, as discussed by Cherednychenko and Meindertsma (2019) in relation to justifications for regulatory intervention to protect consumers from irresponsible lending practices.

The micro-level data in this study consist of foreclosure auction cases at the Swedish Enforcement Authority (SEA, Swe. Kronofogden). Drawing on the work of American sociologist Donald Black (1987), higher socio-economic status is hypothesized to be positively correlated with the potential for compensation in the foreclosure case. This is confirmed in the multivariate linear ordinary least squares (OLS) regression analysis, as higher socio-economic status - operationalized by the variables income, higher education, and marriage — is positively correlated with a greater potential for compensation. In the second part of the analysis, it is demonstrated that appraiser bias is not a likely explanation of these group differences.

I proceed with a background on consumer protection regulation for mortgage borrowers in Sweden and on the Swedish foreclosure process. The literature review outlines the academic discussion on the need for consumer protection for borrowers in foreclosure. In "Data and Method," the main focus is on how the potential for compensation is operationalized. The empirical findings are presented in two parts: Firstly, a multivariate regression analysis to demonstrate the association between the potential for compensation and socio-economic status. Secondly, a bivariate analysis between subgroups of borrowers of low and high socio-economic status and the price-to-market value ratio for the foreclosed properties to demonstrate that appraiser bias is not likely. Finally, the policy implications of these findings are discussed in light of current trends in European consumer regulation.

\section{The Swedish Case of Foreclosure and Consumer Protection}

The foreclosure process in Sweden consists of three phases: debt collection, lawsuit, and foreclosure auction. Debt collection includes all measures regarding termination of contract 
and efforts on behalf of the lender and the borrower to reach a voluntary solution or payment after default. This includes the voluntary sale of the property by the borrower. Debt collection measures, including negotiations, may continue even as the foreclosure process proceeds. As a consequence, foreclosure may be deferred or revoked at any time by the lender upon reaching an agreement with the borrower.

In the lawsuit phase, the lender litigates either in court or at the SEA through summary proceedings in order to establish that the credit contract is terminated and that the lender has the right to enforce payment through foreclosure sale of the collateral real property. This is always also a deficiency judgement, i.e., a non-recourse foreclosure system. This means that the lender is not restricted to payment from foreclosure sale of the collateral only, but can pursue payment of arrears through other enforcement measures, such as garnishment of salary or attachment of other property, after the foreclosure proceedings are concluded (Harris and Meir 2015).

The final phase is the foreclosure auction, which is exclusively carried out by the SEA. The lender applies for foreclosure sale within two months after the verdict or order to pay has come into force. A first attempt at foreclosure sale should be made within four months. The sale is normally carried out at public auction. A brokered sale is possible, but rarely done. If there are no bids, if the highest bid is unreasonably low, or if the lender refuses a bid, at the first auction, then normally a second attempt is made. If this auction does not result in sale, then the case is closed. The lender may then in the future apply for foreclosure sale again using the same verdict. It is quite uncommon that the lender buys the foreclosed property, but there are likely some professional buyers (Donner 2017).

The legal provisions regarding the lawsuit and foreclosure auction phases are in the Summary Proceedings Act (Swe. Lag 1990 om betalningsföreläggande och handräckning) and in the Enforcement Code (Swe. Utsökningsbalk 1981), specifically Chapter 12. Persson et al. (2013, pp. 800-806) provide a comprehensive account of the legal framework.

Market value appraisal is performed in every foreclosure auction case as long as it is not revoked at an early stage. The appraisal is needed as factual grounds for the legal assessment by the SEA of whether a bid at the foreclosure auction is reasonable. The parties are given the opportunity to review the appraisal before the actual foreclosure auction and comment upon it. However, it may be formally challenged only in conjunction with an appeal against the auction itself. The appraisal is meant to reflect the market value for the foreclosed property as if it was sold on the open market in a regular arms-length sale (Donner 2020). The appraisers are professional, in most cases also certified, and external to the SEA. These commissions are publicly procured for a set time period by the SEA, which means that the terms, including payment, are set in advance. The appraisal is normally performed in the first month or two after the initiation of foreclosure auction proceedings. The appraisal of housing properties always includes physical inspection of the property, including the interiors of houses and other buildings. The SEA secures entry by force if necessary. In many cases, the borrower is present at the actual physical inspection, or the appraiser has other contacts with the borrower. The appraiser also acquires any relevant documentation regarding in rem rights or obligations attached to the real property. The appraisers have local knowledge and expertise, since they have to be located within reasonable travelling distance to the property due to the demand for physical inspection. ${ }^{2}$

\footnotetext{
${ }^{2}$ This paragraph draws upon my own extensive operative experience of handling foreclosure auctions at the SEA from circa 2010 until the present day.
} 
I now turn to describing consumer protection regulation in Sweden. This regulation is found in the Consumer Credit Act 2010 (Swe. Konsumentkreditlag 2010), which is applicable to all residential mortgage credit. Sections $7,8,10,12,14$, and 21-25 contain provisions about the sale of credit, e.g., marketing, pre-contractual information, distance sales, underwriting standards, documentation, and withdrawal. Some provisions target the active phase of the credit lifecycle, e.g., changes in interest (Sections 17-19). There are also a few provisions regarding termination of the credit contract. This concerns mainly pre-payment and notice of termination (Sections 32-27). As a result of the implementation of the MCD, a few changes were made to the act. The most significant changes regarded marketing, information, advice, and underwriting (Sections 7a, 9a, 12a, $13 \mathrm{a}-\mathrm{b}, 49$, and 51-54). In summary, the Consumer Credit Act is mostly relevant for credit protection during access to credit. At this stage, it provides adequate consumer protection. By contrast, protection for consumers in default and foreclosure has by large been neglected.

Facultative private law is also relevant for mortgage contracts and their interpretation, for example, the Promissory Notes Act (Swe. Skuldebrevslag 1936) and the Contracts Act (Swe. Avtalslag 1915). However, this body of law has a weaker standardizing effect than consumer protection regulation. Additionally, regulation aimed at consumer protection in a broader understanding may include, for example, compliance and supervisory regulation. Such regulation imposes obligations on the lenders through standards for how to run a business involving the sale or intermediation of residential mortgage loans.

It is noteworthy that the Swedish Government considered that amending the Consumer Credit Act was not necessary to implement MCD Art. 28 regarding arrears and foreclosure. This article contains consumer protection provisions regarding reasonable forbearance of behalf of lenders, a cap on fees, full-recourse contracts, and best efforts price. The reasoning was that the European Banking Authority's (EBA) Guidelines on arrears and foreclosure (2015) are applicable in Sweden for lenders (Bolåneutredningen 2015, p. 268). These guidelines specify how lenders should organize and exercise loss mitigation during mortgage delinquency in order to comply with Art. 28. It remains unclear, however, if and how they are directly enforceable on a specific contractual relationship. Furthermore, with regard to their actual impact on bank operations, case-handling officers responsible for debt collection and loss mitigation at the major Swedish banks rarely refer to the MCD or the guidelines at all when discussing changes in practices during recent years, beyond resulting in stricter requirements regarding documentation. ${ }^{3}$ My conclusion is that it seems as if the implementation of the MCD, which has come into force after the time period that the data in this study cover, has made little impact on consumer protection for Swedish borrowers in foreclosure.

I will now finish this background section with a few words about the relevance of the Swedish case of foreclosure and consumer protection in the European context with regard to compensation. Here I consider the situation before 2015, as this is the time period covered by the data. Most importantly, foreclosures in Sweden are non-recourse just like they are in a majority of the European legal regimes (Harris and Meir 2015). Furthermore, comparing the CCD 2008 with the Swedish Consumer Credit Act 2010, the level of protection offered to consumers in default are similar in the two respective regulations. They both focus on the availability of information for the consumer at the access to credit stage. Thus, Sweden elected to advance no additional substantive consumer protection for consumers in default and was in this regard firmly positioned in the main stream of European consumer protection regimes at

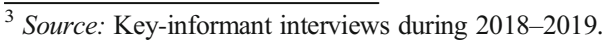


the time. Accordingly, Sweden was comparable to other European legal regimes with regard to these important prerequisites for compensation during foreclosure. This indicates that what can be learnt from studying compensation in the context of Swedish foreclosures should be relevant from a policy perspective also for other European countries.

\section{Consumer Protection during Foreclosure-A Debated Issue}

Here I review the academic debate on the need for consumer status and protection throughout the entire credit lifecycle. The debated issue is whether, given the legal and financial complexity of mortgage credit, consumer protection should be extended also to borrowers in delinquency. This review draws upon regulatory examples from both the EU and the US.

From a legal perspective, the mortgage loan is a fairly complicated product involving personal obligations for the borrower regarding both the protection of the economic value of the real property and the payment of capital, interest, and fees, as well as proprietary obligations connected to the real property as collateral, enabling the lender to capitalize the loan without competition from other creditors upon default. From a financial perspective, mortgage loans are an example of "classical credence goods whose suitability is difficult, if not impossible, for a consumer to effectively assess at the time they are purchased" (Nield 2015, p. 142). Since it is a debt instrument, it concentrates risk on the borrower, even for unforeseen events (Mian and Sufi 2015). Furthermore, the mortgage loan in most cases involves two uneven stakeholders. Mortgage lenders are "repeat players" with superior professional knowledge and organizational capacity in comparison with mortgage borrowers, who are "oneshotters" (Galanter 1974) in these respects. Research indicates that the ability of borrowers to compare between different terms for mortgage loans may be limited (Nield 2010, p. 616). Due to its complexity, disclosure of information is difficult (Nield 2015, p. 143; Whitehouse 1998, p. 198) but has empirically been shown to have some potential during access to credit (Collins 2014; Lacko and Pappalardo 2010). The borrower's position as a "one-shotter" may be further accentuated by structural constraints making other housing alternatives than home ownership unlikely (Whitehouse 1998, pp. 188, 199, 2015, p. 175) and by imperfect market mechanisms governing the supply of mortgage credit (Bar-Gill and Warren 2008; Whitehouse 1998, p. 189).

One way to safeguard the interests of the mortgage borrower, in the face of the complex characteristics of the mortgage contract and the asymmetrical positions of the lender and borrower, is to consider the need for consumer protection throughout the entire lifecycle of the loan. Historically, however, it has not been taken for granted that mortgage borrowers should be awarded protection as consumers at all (Whitehouse 2015). To the extent that the market was regulated to protect consumers, interventions were kept to a minimum so as to not disturb presumed optimal market mechanisms (Nield 2015, p. 144). Modern developments have asserted the legal position of borrowers as consumers, at least from an access to credit perspective. In the European case, the recently adopted MCD, which followed in the wake of the CCD, establishes that mortgage borrowers are consumers in need of protection through standards for responsible lending (De Gioia-Carabellese 2018; Domurath 2015; Mak 2015; Ramsay 2015, pp. 219-221). In the US case, the Dodd-Frank Wall Street Reform and Consumer Protection Act 2010 and the subsequent creation of the Consumer Financial Protection Bureau have brought mortgage loans within the confines of federal consumer protection (Acharya and Richardson 2012; Mierzewski et al. 2010, pp. 18-19). 
The problem is that policy efforts aimed at consumer protection for mortgage borrowers have tended to focus on issues related to access to credit, while ignoring what happens during the rest of the credit lifecycle, including foreclosure (Nield 2015; Whitehouse 2015). Nield (2010, p. 621) argues that the lender's responsibility should stretch for the entire lifecycle of the mortgage loan. She notes that 'the balance between lenders' and mortgagors' interests on default [is] of particular import" (2010, p. 630) and that the UK case "indicate[s] a clear shift towards greater lender responsibility" (2010, p. 629) but that "[n]eo-liberalism remains strong in the context of responsibility for default" (Nield 2015, p. 156). In this context, it is crucial to understand the determinants and development of mortgage industry loss mitigation standards (Stephens and Quilgars 2007; Wallace and Ford 2010). There is also a divide between private law, which regards the consumer as just another player on the free market, and public law, which takes a more "social" interventionistic stance to consumer protection (Domurath 2015; Garcia Porras and Van Boom 2012, pp. 23-24; Whitehouse 2015).

However, there are current examples of polices indicating that a shift is taking place towards also extending consumer protection to mortgage default and foreclosure. In the EU context, one such example is MCD Art. 28 with the complementary EBA guidelines. Implementation by member states can be expected to be diversified (De Gioia-Carabellese 2018; Mak 2015; Ramsay 2015, p. 206). The US Consumer Financial Protection Bureau in 2013 issued new rules regarding mortgage servicing, including requirements pertaining to servicing upon delinquency and default (Dewar 2013; Mierzewski et al. 2013). Cordell and Lambie-Hanson (2016) predict that these servicing rules will lengthen the foreclosure timeline and question the benefits of such additional moratoria in an already long process. From a legal perspective, different borrower strategies to challenge foreclosure proceedings in the postfinancial crisis era have been examined (Davidson 2013; Martin 2016). Looking beyond strict consumer protection regulation in the US, researchers have also evaluated the impact of mortgage default counselling (Collins et al. 2013) and other state interventions aimed at consumer protection for borrowers in economic hardship (e.g., Collins and Urban 2014).

This review demonstrates that there is a quite recent thrust in the academic debate towards extending consumer protection to borrowers in foreclosure and that there are some regulatory initiatives to this effect. This empirical study informs this debate by examining both this group of consumers and the mechanisms that govern the foreclosure process. Such empirical work is essential when considering policy implications (Fox O’Mahony et al. 2015, p. 114).

\section{Data and Method}

This section describes the data set, followed by explanations concerning the operationalization of the potential for compensation (the dependent variable) and socio-economic status (the independent variables). This is followed by a presentation of the multivariate OLS regression framework employed in the analysis.

\section{Data}

The data set consists of foreclosure case-level data from the SEA register on foreclosure auctions from 2000 to 2014. Only cases regarding mortgage credit and housing properties are included. The SEA data contain case-specific variables about the lender(s), the borrower(s), type and location of the property, and events during case proceedings, including outcome. 
Although the SEA data are case-specific, there are also individual-level data about every borrower subject to foreclosure. The borrowers are identified by their Swedish personal identity numbers. This makes it possible to attach socio-economic variables to each borrower. These socio-economic variables were retrieved from the registers of Statistics Sweden, which is the government agency responsible for compiling, storing, and distributing official statistics and micro-level data in Sweden. Statistics Sweden also merged and de-identified the data. ${ }^{4}$

In the final merged data set, there are variables at two levels: case and borrower. The dependent variable is available at the case level. The socio-economic variables are available at the borrower level. This data structure requires that all borrower-level data are aggregated to the case level. All variables and modes of aggregation are described in the code book (Table 1).

\section{Operationalization of the Potential for Compensation}

The dependent variable in this study is the potential for compensation during foreclosure. It measures the potential for payment as an observable variable of the behaviour of law, its modus operandi or what Donald Black refers to as its style $(1976,1987)$, rather than its consequences in the form of, for example, the actual sales price. The compensatory potential of law is relevant for all possible outcomes of foreclosure, not just the possibility that the property is actually sold at foreclosure auction. Besides compulsory sale, foreclosure may result in, for example, voluntary sale of the property or a temporary or permanent loan modification that enables the borrower to cure default (e.g., Been et al. 2013; Chan et al. 2014). As stated in the background section on the Swedish foreclosure process, the lender and borrower may negotiate about alternative solutions through the entire process. In these negotiations, the possibilities are delimited by, amongst other factors, this potential for future payment. ${ }^{5}$ For example, greater compensatory potential, all other things equal, may increase the chances of voluntary sale because voluntary sale probably results in a higher sale price (Donner et al. 2016) and, consequently, there is more to win. If the borrower attempts to avoid compulsory sale by refinancing the mortgage at a different bank, a greater potential for compensation should increase his or her chances of success. Thus, by focusing on compensation as the potential for payment, no available options for the stakeholders are precluded in the analysis.

This understanding of the potential for compensation is operationalized by two variables: appraised market value and tax value. Market value is the dependent variable in the regression model, while tax value is an independent variable. The appraised market value is a measure of the actual market value of the real property at the time of foreclosure as if it was sold in an arms-length voluntary transaction (Donner 2020). Market value appraisal is commissioned in every foreclosure auction case at the SEA. The appraisal procedure is objective and professional, as described in the background section on the Swedish case. Extant research on appraisal accuracy indicates that these preconditions are favourable in the sense that the appraisal may be assumed to result in an accurate estimate of the true market value (Zhu and Pace 2012).

\footnotetext{
${ }^{4}$ Micro-level socio-economic data at Statistics Sweden are not public but may be accessed for research purposes. This research project has been subject to ethical review.

${ }^{5}$ In related research on the same data, I find that higher property market value, holding debt equal, is correlated with a higher propensity for lenders to revoke foreclosure auction proceedings. The manuscript is available upon request.
} 
Table 1 Code book

\begin{tabular}{|c|c|c|c|c|c|}
\hline Variable & Coding & Time & Source & Level & Aggr. \\
\hline Market value & tSEK & $t$ & SEA & Case & No \\
\hline Tax value & tSEK & $t$ & SEA & Case & No \\
\hline Total debt & tSEK & $t$ & SEA & Case & No \\
\hline Auction Price & tSEK & $t$ & SEA & Case & No \\
\hline $\begin{array}{l}\text { Market } \\
\text { value-to-tax } \\
\text { value ratio }\end{array}$ & Market value divided by tax value (derived) & $t$ & SEA & Case & No \\
\hline $\begin{array}{l}\text { Loan-to-value } \\
\quad \text { ratio }\end{array}$ & Debt divided by market value (derived) & $t$ & SEA & Case & No \\
\hline $\begin{array}{l}\text { Price-to-market } \\
\text { value ratio }\end{array}$ & Price divided by market value (derived) & $t$ & SEA & Case & No \\
\hline $\begin{array}{l}\text { Also } \\
\text { non-mortgage } \\
\text { debt }\end{array}$ & $0=$ No, $1=$ Yes & $t$ & SEA & Case & No \\
\hline $\begin{array}{l}\text { Municipality } \\
\text { population } \\
\text { change }\end{array}$ & $\begin{array}{l}\text { Number of residents who moved to (positive) or from } \\
\text { (negative) the municipality where the real property is } \\
\text { located in comparison with the preceding year }\end{array}$ & $t$ & $\mathrm{SCB}$ & Case & No \\
\hline $\begin{array}{l}\text { Borrower is } \\
\text { residential }\end{array}$ & $0=$ No, $1=$ At least one borrower resides at property & $t$ & $\mathrm{SCB}$ & Borr. & Max \\
\hline $\begin{array}{l}\text { Household } \\
\text { income }\end{array}$ & Total household yearly disposable income, tSEK & $t-1$ & SCB & Borr. & Max \\
\hline Other assets & Net wealth minus tax value plus debt, tSEK & $t-1$ & SCB & Borr. & Sum \\
\hline $\begin{array}{l}\text { Higher } \\
\text { education }\end{array}$ & $\begin{array}{l}0=\text { No borrower with post-secondary school education, } \\
1=\text { At least one borrower with post-secondary school } \\
\text { education }\end{array}$ & $t-1$ & $\mathrm{SCB}$ & Borr. & Max \\
\hline Employment & $\begin{array}{l}\text { Proportion of employed borrowers in the case, ranges } \\
\text { from } 0 \text { to } 1\end{array}$ & $t-1$ & $\mathrm{SCB}$ & Borr. & Proportion \\
\hline $\begin{array}{l}\text { Married } \\
\text { household }\end{array}$ & $0=\mathrm{No}, 1=\mathrm{Yes}$ & $t$ & $\mathrm{SCB}$ & Borr. & Recoded \\
\hline Sex & $\begin{array}{l}\text { Proportion of male borrowers in the case, ranges from } 0 \\
\text { to } 1\end{array}$ & $t$ & SEA & Borr. & Proportion \\
\hline Age & $\begin{array}{l}\text { Mean age in years at time of initiation of foreclosure } \\
\text { auction case at SEA }\end{array}$ & $t$ & SEA & Borr. & Mean \\
\hline Born in Sweden & $\begin{array}{l}0=\text { All borrowers not born in Sweden, } 1=\text { All borrowers } \\
\text { born in Sweden }\end{array}$ & $t$ & $\mathrm{SCB}$ & Borr. & Min \\
\hline Year & Year dummies for $2000-2014$ & $t$ & SEA & Case & No \\
\hline $\begin{array}{l}\text { Property } \\
\text { location }\end{array}$ & Municipality dummies for property location & $t$ & SCB & Case & No \\
\hline
\end{tabular}

Note: tSEK 1.0 equals SEK 1,000. Money value adjusted to year 2014. Time refers to when the variable is measured: $t$ is the year when the foreclosure case was initiated and $t-1$ is the preceding year. Source refers to the Swedish Enforcement Authority (SEA) and Statistics Sweden (SCB). Level specifies whether a given variable is observed at the case or borrower level in the original data. Aggr. specifies which type of aggregation was performed from the borrower to the case level when adapting the data to fit the regression framework. "Mean" presents mean value for all borrowers in a case. "Max" presents the highest value for any borrower in the case. "Min" presents the lowest value for any borrower in the case. "Proportion" presents a value for the proportion of borrowers with a specific characteristic in the case. "Recoded" presents values according to the coding for that specific variable

However, the property's appraised market value cannot operationalize the potential for compensation on its own, since this would mean that a higher market value is always equated with a greater potential. A property with a low appraised market value may represent a large potential for payment if its appearance and maintenance is superior to other comparable 
properties. Thus, a meaningful operationalization of the potential for compensation requires that it is a relative measure. What is required is a reference estimate of the property's typical market value considering its location and characteristics. If the appraised market value is controlled by this typical market value, it may be interpreted not as an absolute value, but rather as a relative measure that is relevant for the potential for payment during foreclosure. In the language of regression modelling, this allows isolation of variation related to the typical market value from the correlation between the appraised market value and socio-economic status. Fortunately, in the Swedish case, the typical market value for real property is available as its tax value.

The real property's tax value is set by the Swedish Tax Agency. It is meant to correspond to $75 \%$ of the property's market value as of two years before its estimation. It is normally re-estimated every third year. The procedure for re-estimation in most cases involves the owner answering quite detailed questions about the property in writing. This information, in conjunction with local sales prices during the third and fourth years preceding the re-estimation, forms the basis for the Tax Agency's decision about a new tax value. From a fiscal perspective, the tax value determines how high the property tax is. However, this tax is quite low, a maximum of approximately SEK 8,000 annually, and increases only up to an approximate tax value of SEK 1,000,000 for a housing property. As a result, there should be little fiscal incentive for homeowners to provide the Tax Agency with false information in order to obtain a low tax value. Hence, the tax value should provide a fairly accurate estimate of the property's typical market value with the caveat that there is a time lag for the reference market values.

\section{Socio-economic Variables}

The focus in this study is on the correlation between the potential for compensation and the socio-economic status of the borrowers in foreclosure. The socio-economic status is operationalized by several independent variables. These variables are annual household disposable income, higher education, employment, family type, sex, age, and born in Sweden. Income is nominally measured in SEK with money value adjusted to year 2014. Higher education is a dummy variable indicating that at least one of the borrowers in a foreclosure auction case has any post-secondary school education. Employment codes the proportion of borrowers in a case that are working as a value between 0 and 1. Family type is a dummy variable indicating that the borrower(s) in a case are married. Sex is coded as the proportion of male debtors in the same way as for employment. Age is the mean value in years for all borrowers in a case. Born in Sweden is a dummy variable indicating that all of the borrowers are born in Sweden.

The operationalization of socio-economic status with these variables is consistent with the socio-legal conceptual framework of this study, inspired by Donald Black (1976, 1984). In this framework, socio-economic status encompasses not only fairly standard objective indicators such as income, occupation, and education (Galobardes et al. 2007), which focus on wealth and achievement. It also includes indicators of societal integration, operationalized by the family type variable, and indicators of who the borrower is in terms of sex, age, and birth country. Similar variables have been used in previous empirical research on foreclosure outcomes (e.g., Been et al. 2013; Chan et al. 2014; Voicu et al. 2012). 


\section{Regression Framework}

The main regression model is described by the following equation:

$$
\begin{gathered}
\text { Market value }_{i t m}=\beta_{0}+\beta_{1} \text { Income }_{i}+\beta_{2} \text { Education }_{i}+\beta_{3} \text { Employment }_{i}+\beta_{4} \text { Family type }_{i}+ \\
+\beta_{5} \text { Sex }_{i}+\beta_{6} \text { Age }_{i}+\beta_{7} \text { Born in Sweden }_{i}+\beta_{8} \text { Tax value }_{i}+\delta_{1} \text { Controls }_{i}+\gamma_{1} \text { Year }_{t}+\gamma_{2} \text { Location }_{m}+\varepsilon_{\text {itm }}
\end{gathered}
$$

where the market value for case $i$ in year $t$ and property location $m$ is the dependent variable, $\beta_{1}$ to $\beta_{7}$ are the coefficients for the socio-economic variables, $\beta_{8}$ is the coefficient for the tax value variable, $\delta_{1}$ is a vector for the remaining independent variables not pertaining to socioeconomic status, $\gamma_{1}$ is a fixed effect for year, $\gamma_{2}$ is a fixed effect for property location on the municipality level, $\beta_{0}$ is the constant, and $\varepsilon$ is the error term. The regression link estimates the parameters using the linear ordinary least squares method. The fixed effects are suppressed in the presentation of the results. In an alternative model specification, $\beta_{9}$ is added as the coefficient for other assets.

Donald Black suggests that compensation "seems [...] to vary directly with the social status of the liable party" (1987, p. 572). The regression model aims to evaluate this proposition that higher socio-economic status should be correlated with more compensation. Accordingly, the expectation is that the coefficient signs for socio-economic variables indicating higher status should be positive and significant. Higher income and other assets imply greater access to money and property. Employment and marriage imply greater integration into society. Higher education implies academic achievement. Being male, older, and born in Sweden imply higher personal status.

\section{Results}

The first research question, exploring how the potential for compensation varies for borrowers of different socio-economic status, is first analysed in a bivariate setting to demonstrate that borrowers seem to have different socio-economic status depending on some important indicators of the property's economic status and condition. Then I employ the multivariate OLS regression framework described above to evaluate whether these bivariate associations are stable when modelled simultaneously and if the coefficients behave as expected. The second research question, exploring how this association between compensatory potential of foreclosure and socio-economic status may be explained, is assessed through a descriptive and bivariate analysis of the price-to-market value ratio across subsets of borrowers with the aim of discerning whether there are group differences related to socio-economic status.

\section{Descriptive Statistics}

Descriptive statistics for the regression sample are presented in Table 2. This table also includes a few derived variables not used in the regression model, such as the loan-to-value ratio. The main takeaways are that the foreclosed properties' market values are quite low ( $\mathrm{p} 50=$ SEK 528000), that the ratio between market value and tax value is quite close to the expected value of 1.33 (mean $=1.29$ ), that LTV ratios do not seem to be aggressively high for the majority of the foreclosed households $(\mathrm{p} 50=0.83)$, that the properties are eventually sold at foreclosure auction at a price lower than the appraised market value (p50 for price-to-market value ratio $=0.80$ ), and that the typical socio-economic profile for a Swedish borrower in 
Table 2 Descriptive statistics

\begin{tabular}{|c|c|c|c|c|c|c|c|}
\hline & Mean & SD & Min & Max & $\mathrm{p} 25$ & p50 & p75 \\
\hline Market value & 943.5 & 1255.0 & 0 & 18119.1 & 249.8 & 528.2 & 1100.0 \\
\hline Tax value & 696.3 & 751.9 & 0 & 10052.0 & 276.9 & 456.1 & 807.3 \\
\hline Total debt & 703.9 & 1306.8 & 0.60 & 47254.5 & 200.0 & 378.8 & 743.3 \\
\hline Market value-to-tax value ratio ${ }^{a}$ & 1.29 & 0.99 & 0 & 33.6 & 0.81 & 1.20 & 1.56 \\
\hline Loan-to-Value ratio ${ }^{\mathrm{b}}$ & 468.2 & 21687.7 & 0.000067 & 1490751.0 & 0.43 & 0.83 & 1.34 \\
\hline Auction price ${ }^{c}$ & 671.5 & 1028.8 & 8.4 & 13965.0 & 140.8 & 324.2 & 751.1 \\
\hline Price-to-market value ratio ${ }^{\mathrm{d}}$ & 93.9 & 2668.3 & 0.053 & 110000.0 & 0.63 & 0.80 & 1.00 \\
\hline \multicolumn{8}{|l|}{ Also non-mortgage debt } \\
\hline Yes & .16 & .36 & 0 & 1 & 0 & 0 & 0 \\
\hline Municipality population change & 331.0 & 1243.0 & -11437 & 17656 & -60 & 36 & 318 \\
\hline \multicolumn{8}{|l|}{ Borrower is residential } \\
\hline Yes & .71 & .45 & 0 & 1 & 0 & 1 & 1 \\
\hline Household income & 254.5 & 174.5 & -22.5 & 2526.7 & 136.9 & 222.3 & 347.2 \\
\hline Other assets ${ }^{\mathrm{e}}$ & 170.4 & 2746.8 & -118460.5 & 51808.0 & -134.2 & 77.3 & 335.5 \\
\hline \multicolumn{8}{|l|}{ Higher education } \\
\hline Yes & .19 & .39 & 0 & 1 & 0 & 0 & 0 \\
\hline Employment & .51 & .46 & 0 & 1 & 0 & .5 & 1 \\
\hline \multicolumn{8}{|l|}{ Married household } \\
\hline Yes & .40 & .49 & 0 & 1 & 0 & 0 & 1 \\
\hline Sex & .66 & .36 & 0 & 1 & .5 & .5 & 1 \\
\hline Age & 47.4 & 11.0 & 20 & 92 & 40 & 47 & 54 \\
\hline \multicolumn{8}{|l|}{ Born in Sweden } \\
\hline Yes & .84 & .37 & 0 & 1 & 1 & 1 & 1 \\
\hline$N$ & 7,104 & & & & & & \\
\hline
\end{tabular}

Note: All mortgage foreclosure auction cases regarding housing properties for years 2000-2014 are included. tSEK 1.0 = SEK 1,000=USD 100.4=EUR 91.1 (Retrieved from https:/www.riksbank.se/en-gb/statistics/, (accessed 28 March 2020))

a $N=7,103$

b $N=7,091$

${ }^{\mathrm{c}} N=3,199$ (not all cases result in sale due to revocations)

${ }^{\mathrm{d}} N=3,195$ (not all cases result in sale due to revocations)

${ }^{\text {e }} N=3,777$ (available for years 2000-2008 only)

foreclosure is a single, middle-aged male without higher education and with quite low household income (p50 = SEK 222000).

\section{Bivariate Analysis of the Potential for Compensation}

The derived variable for the market value-to-tax value ratio (MV/TV) measures the level of compensatory potential in a specific case, i.e., the potential for payment, as discussed previously. If it is true that there is a correlation between the potential for compensation and socio-economic status, we would expect that the values for the socio-economic variables are different for different segments of borrowers according to whether there is a high or low MV/ TV ratio. This statement is evaluated descriptively and with significance tests for bivariate associations in Table 3. This table also includes loan-to-value ratio (LTV) as a measure of how underwater the foreclosed property is. In this table, the borrowers are divided into high and low subgroups according to these measurements, and select descriptive statistics are presented for the socio-economic variables together with $t$ tests for continuous variables and chi-squared tests for categorical variables. Just as expected, the borrowers with low-compensation 
Table 3 Descriptive statistics and bivariate associations between the socio-economic variables and borrower subgroups by market value-to-tax value ratio and loan-to-value ratio

\begin{tabular}{|c|c|c|c|c|}
\hline & \multicolumn{2}{|c|}{ Market value-to-tax value ratio } & \multicolumn{2}{|c|}{ Loan-to-value ratio } \\
\hline & Low & High & High & Low \\
\hline \multicolumn{5}{|l|}{ Household income } \\
\hline Mean & $222.0^{\text {** }}$ & $286.9^{* *}$ & $232.5^{* *}$ & $276.5^{* *}$ \\
\hline Median & 198.0 & 255.3 & 202.3 & 245.5 \\
\hline Interquartile range & 175.7 & 234.8 & 186.7 & 223.4 \\
\hline \multicolumn{5}{|l|}{ Higher education } \\
\hline Share & $.14 \dagger$ & $.23^{\dagger \dagger}$ & $.17^{\dagger \dagger}$ & $.21^{\dagger \dagger}$ \\
\hline \multicolumn{5}{|l|}{ Employment } \\
\hline Mean & $.47^{* *}$ & $.56^{* *}$ & $.47^{* *}$ & $.56^{* *}$ \\
\hline \multicolumn{5}{|l|}{ Married household } \\
\hline Share & $.31^{\dagger \dagger}$ & $.49^{\dagger \dagger}$ & $.34 \dagger$ & $.46^{\dagger \dagger}$ \\
\hline \multicolumn{5}{|l|}{ Sex } \\
\hline Mean & $.66^{*}$ & $.65^{*}$ & $.67^{* *}$ & $.64^{* * *}$ \\
\hline \multicolumn{5}{|l|}{ Age } \\
\hline Mean & $47.1^{*}$ & $47.6^{*}$ & $46.5^{* *}$ & $48.3^{* *}$ \\
\hline \multicolumn{5}{|l|}{ Born in Sweden } \\
\hline Share & .84 & .84 & $.82^{\dagger \dagger}$ & $.86^{\dagger \dagger}$ \\
\hline$N$ & 3,551 & 3,553 & 3,558 & 3,546 \\
\hline
\end{tabular}

Note: All mortgage foreclosure auction cases regarding housing properties for years 2000-2014 are included. Cut-off values for the low and high subgroups are the median values according to Table 2 . The high subgroup for market value-to-tax value ratio includes all observations equal to or higher than the median value. The low subgroup for loan-to-value ratio includes all observations equal to or lower than the median value. The columns for the LTV subgroups are reversed to indicate that the high subgroup has weaker socio-economic resources

Significance levels for independent two-sample $T$ tests of difference in means: ${ }^{*} p<.05,{ }^{* *} p<.01$

Significance levels for Pearson's chi-squared test of independence: ${ }^{\dagger} p<.05,{ }^{\dagger \dagger} p<.01$

properties, i.e., the low MV/TV ratio subgroup, or with properties that are more deeply in debt, i.e., the high LTV ratio subgroup, generally have a lower socio-economic status. These subgroups all have lower mean and median household incomes and are employed to a lesser extent. They have less higher education. They are single to a higher extent and have fewer children. These differences are substantial. $T$ tests for differences in means are generally significant, as are the Pearson chi-squared statistics for the categorical variables. Only for the sex, age, and born in Sweden variables are there smaller differences between the high and low subgroups.

This bivariate analysis indicates that there are socio-economic group differences for borrowers in foreclosure in relation to the potential for compensation. Furthermore, it indicates that these group differences correspond to the expectation that the law's potential to compensate low-status borrowers is lower than for high-status borrowers. This provides tentative evidence that socio-economically weaker borrowers are more vulnerable in terms of less potential for compensation.

\section{Multivariate Analysis of the Potential for Compensation}

In the multivariate OLS regression model, appraised market value is regressed on vectors of socio-economic, control, and fixed-effects variables. The aim is to test whether market value, which after controlling for tax value operationalizes the potential for compensation, covaries 
with the socio-economic variables. The coefficient sign for the socio-economic variables is indicative of the direction of the association with the potential for compensation, which is my main interest.

Table 4 presents the regression results in two columns. Model 1 is the full model, with all mortgage foreclosure auction cases regarding housing properties at the SEA from 2000 to $2014(N=7,104)$. The model is statistically significant $(\mathrm{F}(313)=104.5, p<.001)$. The relatively high number of degrees of freedom is explained by the inclusion of many fixed-effect dummies for real property location at the municipality level. A substantial part of the variance is explained, since the $R^{2}$ value is high at .828 (adjusted $R^{2}=.820$ ). This is expected since tax value is a strong predictor of market value in the model. Model 2 contains one additional independent variable: other assets. This variable measures whether the borrower has other net assets besides the real property and is available for years 2000-2008 only, which explains the smaller sample $(N=3,777)$.

According to the results for the socio-economic variables in Model 1, the coefficients predominantly behave as expected from the bivariate analysis. The income variable is statistically significant at $p<.01$ and the direction of the correlation is positive, as expected. For the education variable, the coefficient sign is positive and significant. This dummy variable indicates that at least one borrower in the foreclosure auction case has higher education. The employment variable, measuring the proportion of employed borrowers in a case, has a negative coefficient sign and is not statistically significant. Family type consists of a dummy for married households. This married dummy is significant and positive, as expected. There are no statistically significant correlations for the sex and age variables. The dummy for cases with all borrowers born in Sweden is positive in the regression model, but not significant. ${ }^{6}$

In Model 2, the coefficients for the socio-economic variables are stable in terms of both sign and significance. The added variable - other assets - does not behave as expected since it is negative and weakly significant. The presence of other assets besides the foreclosed property indicates higher socio-economic status. Hence, the expectation was that the coefficient would be positive.

This concludes the analysis aimed at evaluating the association between the potential for compensation and socio-economic status. As expected, the main results indicate that there is a positive correlation between borrower socio-economic status and the compensatory potential of foreclosure. This is true in the regression model for three key socio-economic variables: income, education, and family type. I now move to the second part of the analysis, in which I analyse one possible explanation for the observed group differences.

\section{Bivariate Analysis of the Price-to-Market Value Ratio}

In this final part of "Results," the aim is to analyse whether it is probable that the correlation between a greater potential for compensation and higher socio-economic status is explained by appraiser bias. Appraiser bias is an example of a factor that may explain these group differences. This is possible because the data contain not only appraised market value but also the actual sale price observed for those cases that result in sale at foreclosure auction. As

\footnotetext{
${ }^{6}$ When removing outliers according to Cook's distance, the coefficient for the employment variable becomes positive and significant at $p<.10$ and the coefficient for the born in Sweden variable becomes significant at $p<.10$. The remaining independent variables are stable in terms of direction and significance in this specification. Regression table is available upon request.
} 
Table 4 Estimated coefficients from multivariate ordinary least squares (OLS) regression models predicting the appraised market value in foreclosure auction cases

(1)

\begin{tabular}{|c|c|c|}
\hline Tax value & $\begin{array}{l}1.307^{* *} \\
(0.0135)\end{array}$ & $\begin{array}{l}1.362^{* *} \\
(0.0246)\end{array}$ \\
\hline Total debt & $\begin{array}{l}0.0464^{* *} \\
(0.00570)\end{array}$ & $\begin{array}{l}0.0104 \\
(0.00710)\end{array}$ \\
\hline \multicolumn{3}{|l|}{ Also non-mortgage debt } \\
\hline Yes & $\begin{array}{l}61.68^{* *} \\
(18.93)\end{array}$ & $\begin{array}{l}75.38^{* *} \\
(22.62)\end{array}$ \\
\hline Municipality population change & $\begin{array}{l}-0.0127 \\
(0.0124)\end{array}$ & $\begin{array}{l}0.0234 \\
(0.0177)\end{array}$ \\
\hline \multicolumn{3}{|l|}{ Debtor is residential } \\
\hline Yes & $\begin{array}{l}76.57^{* *} \\
(14.88)\end{array}$ & $\begin{array}{l}49.52^{* *} \\
(18.61)\end{array}$ \\
\hline Household income & $\begin{array}{l}0.245^{* *} \\
(0.0481)\end{array}$ & $\begin{array}{l}0.283^{* *} \\
(0.0646)\end{array}$ \\
\hline \multicolumn{3}{|l|}{ Higher education } \\
\hline Yes & $\begin{array}{l}75.59^{* *} \\
(17.42)\end{array}$ & $\begin{array}{l}39.68^{+} \\
(22.71)\end{array}$ \\
\hline Debtor employment & $\begin{array}{l}-10.10 \\
(15.87)\end{array}$ & $\begin{array}{c}-25.90 \\
(19.39)\end{array}$ \\
\hline \multicolumn{3}{|l|}{ Married household } \\
\hline Yes & $\begin{array}{l}45.74^{* *} \\
(15.73)\end{array}$ & $\begin{array}{l}40.57^{*} \\
(19.51)\end{array}$ \\
\hline Sex & $\begin{array}{c}-3.094 \\
(18.21)\end{array}$ & $\begin{array}{l}0.813 \\
(22.29)\end{array}$ \\
\hline Age & $\begin{array}{l}1.822^{* * *} \\
(0.613)\end{array}$ & $\begin{array}{l}1.254 \\
(0.789)\end{array}$ \\
\hline \multicolumn{3}{|l|}{ Born in Sweden } \\
\hline Yes & $\begin{array}{l}27.12 \\
(18.44)\end{array}$ & $\begin{array}{l}19.48 \\
(24.63)\end{array}$ \\
\hline Other assets & & $\begin{array}{l}-0.00568^{+} \\
(0.00332)\end{array}$ \\
\hline Constant & $\begin{array}{l}460.4^{*} \\
(193.8)\end{array}$ & $\begin{array}{l}249.1 \\
(277.6)\end{array}$ \\
\hline$N$ & 7104 & 3777 \\
\hline$F$ & 104.5 & 47.4 \\
\hline$D F$ & 313 & 308 \\
\hline$p$ & $<.001$ & $<.001$ \\
\hline$R^{2}$ & .828 & .808 \\
\hline Adjusted $R^{2}$ & .820 & .791 \\
\hline
\end{tabular}

Note: Standard errors in parentheses. Fixed effects for year and property location are suppressed Regression samples:

(1) All mortgage foreclosure auction cases regarding housing properties for years 2000-2014

(2) All mortgage foreclosure auction cases regarding housing properties for years 2000-2008

$+p<.10$

${ }^{*} p<.05$

*** $p<.01$

presented in Table 2, the auction price is lower than the appraised market value in most cases: only at the 75th percentile does the ratio between price and market value even out at 1 . Appraiser bias is analysed by comparing the price-to-market value ratios for borrowers of high versus low socio-economic status. If there is appraiser bias, I expect that this ratio is lower for 
high socio-economic status borrowers compared to the low subgroup. This is because, if appraisers are biased, they will systematically over-estimate the market values for houses belonging to the high socio-economic status subgroup in relation to the actual sale price. This is true at least as a relative comparison between the low and high subgroups under the assumption that the market conditions for the sale are similar for both subgroups.

Table 5 presents descriptive statistics for the price-to-market value ratios of subgroups of borrowers with high versus low values for the selected socio-economic variable together with significance levels for $t$ tests. Outliers in terms of observations with price-to-market value ratios below the first percentile and above the 99th percentile have been removed to be able to compare means. According to the table, mean and median values for the price-to-market value ratio are quite similar across the high and low subgroups for all of the socio-economic variables. Furthermore, there are no distinct patterns with systematically lower values for the high subgroups than for the low subgroups. Mean values range from .85 to .90 . The high subgroups have lower mean values for the income, family type, employment, and born in Sweden variables. However, differences in means are statistically significant at $p<.05$ only for the employment variable. Median values range from .80 to .84 and differ by no more than .02 between the high and low subgroups across all the socio-economic variables, except for the education variable. For the education variable, the median value is higher for the high subgroup than for the low subgroup. This is the opposite direction of the expected effect of appraiser bias. The same is true for the family-type variable. ${ }^{7}$

In conclusion, these results indicate that there are no group differences in the price-tomarket-value ratio across borrower subgroups defined by high versus low socio-economic status. This finding provides evidence that the appraised market values are not biased in this regard. I discuss the policy implications of the empirical findings in this study next.

\section{Policy Discussion}

Drawing on the literature on consumer regulation, my argument is twofold. Firstly, to safeguard the interests of borrowers in default, it is necessary to consider the possibilities of both strict consumer protection and other safety nets. Secondly, in the absence of empirical evidence regarding the explanation of socio-economic group differences, the reallocation of risk beyond the stakeholders of the credit contract through the activation of diverse safety nets is preferable to blind implementation of consumer protection regulation. The focus is on the European context, given that Sweden is similar to other European legal regimes in that foreclosures are non-recourse and the level of consumer protection for mortgage borrowers is comparable.

Concurrently with the financial inclusion paradigm, with information as the guiding principle for consumer protection, there has since the CCD been a trend towards a financial stability paradigm, with the implementation of consumer protection also through substantive regulation (Aldohni 2017; Domurath 2013; Oehler and Wendt 2017; Ramsay and Williams 2020, pp. 215-216). The MCD, in comparison with the CCD, illustrates this parallel development with its stricter requirements regarding the creditworthiness assessment and the decision to deny credit, and also new provisions regarding default and foreclosure

\footnotetext{
${ }^{7}$ This bivariate analysis is confirmed in a multivariate OLS regression with the price-to-market value ratio as the dependent variable predicted by the socio-economic variables. Tables are available upon request.
} 
Table 5 Descriptive statistics and bivariate associations between price-to-market value ratios and borrower subgroups for selected socio-economic variables

\begin{tabular}{|c|c|c|c|c|c|c|c|c|}
\hline & $N$ & Mean & SD & Min & Max & $\mathrm{p} 25$ & p50 & p75 \\
\hline \multicolumn{9}{|l|}{ Household income } \\
\hline Low & 1,812 & 0.88 & 0.46 & 0.17 & 3.60 & 0.60 & 0.80 & 1.02 \\
\hline High & 1,325 & 0.86 & 0.38 & 0.17 & 3.50 & 0.65 & 0.80 & 1.00 \\
\hline \multicolumn{9}{|l|}{ Education } \\
\hline No higher & 2,558 & 0.87 & 0.44 & 0.17 & 3.60 & 0.61 & 0.80 & 1.00 \\
\hline Higher & 579 & 0.89 & 0.39 & 0.17 & 3.33 & 0.69 & 0.84 & 1.01 \\
\hline \multicolumn{9}{|l|}{ Family type } \\
\hline Not married & 2,201 & 0.88 & 0.45 & 0.17 & 3.60 & 0.61 & 0.80 & 1.01 \\
\hline Married & 936 & 0.86 & 0.38 & 0.17 & 3.20 & 0.66 & 0.82 & 0.98 \\
\hline \multicolumn{9}{|l|}{ Employment } \\
\hline Not all working & 1,510 & $0.90^{* *}$ & 0.49 & 0.17 & 3.60 & 0.62 & 0.80 & 1.03 \\
\hline All working & 1,214 & $0.85^{* *}$ & 0.38 & 0.17 & 3.30 & 0.63 & 0.80 & 1.00 \\
\hline \multicolumn{9}{|l|}{ Born in Sweden } \\
\hline Not all Swedish & 600 & 0.88 & 0.42 & 0.17 & 3.60 & 0.66 & 0.82 & 1.00 \\
\hline All Swedish & 2,537 & 0.87 & 0.43 & 0.17 & 3.50 & 0.62 & 0.80 & 1.00 \\
\hline
\end{tabular}

Note: All mortgage foreclosure auction cases regarding housing properties for years 2000-2014 are included, except for cases with values for price-to-market value ratio below 1st percentile and above 99th percentile

a Subgroups by median household income; see Table 2. The high subgroup includes all observations equal to or higher than the median value

Significance levels for independent two-sample $T$ tests of difference in means: ${ }^{*} p<.05,{ }^{* *} p<.01$

(Cherednychenko 2014; Cherednychenko and Meindertsma 2019; Ferretti 2015; Ramsay 2016).

The academic discussion about this regulatory shift indicates that substantive regulation, such as price caps, is now possible in order to protect consumers when accessing credit but that we have yet to see the full impact of this trajectory for consumers in default. According to Ramsay and Williams (2020), an emerging financial stability paradigm includes individual bankruptcy for consumers as a benchmark in international soft law. Ferretti, referring to "both preventive and curative measures" (2015, p. 375) makes a similar point in relation to countering over-indebtedness. With regard to mortgage credit specifically, Domurath (2016) suggests that there is a need to allow ex post reallocation of risk due to unforeseen changing economic circumstances for the consumer. Micklitz (2016, p. 40) demonstrates that a constitutional dimension to what essentially constitutes private law conflicts over mortgage contracts is gaining significance in response to increasing exposure of consumers to market mechanisms.

Furthermore, it should be considered that consumer protection is but a single safety net for mortgage borrowers in a complex web of safety nets. I use safety nets to denote diverse and partially overlapping protective policies, private and public, for mortgage borrowers in foreclosure. These safety nets include private insurance protection (Cowan 2011, p. 334; Ford 2012; Ford and Quilgars 2001), welfare policies (Cowan 2011, p. 334; Ford and Quilgars 2001; Nield 2015; Squires and Hyra 2010, pp. 55-56; Wallace 2012, p. 127; Whitehouse 1998, p. 204), and insolvency regulation, including variations of bankruptcy and debt relief law (Levitin and Goodman 2008; Porter 2008; Ramsay 2015). These safety nets target the redistribution of risk between the lender and the borrower, and also to other stakeholders, public and private. In mortgage credit contracts, the risk of arrears is centred on the borrower, even for events beyond his or her control, such as macro-economic trends or crises (Mian and Sufi 2015). This is further 
accentuated in the typical European foreclosure system, since it is non-recourse. Moreover, the safety nets are to some extent contingent on national welfare policies since such policies partially shift this risk onto the state. In the Swedish case, the welfare state, at least historically, has provided its citizens with quite extensive insurance coverage compared to other countries in the northern hemisphere regarding, for example, unemployment, health, and child care (EspingAndersen 1990, pp. 26-29; Svallfors 2004, pp. 121-123).

Cherednychenko and Meindertsma argue that market failures justify consumer protection regulation and that interdisciplinary research should investigate these market failures and how to remedy them (2019, pp. 490-491, 513-514). My contention is that, in absence of positive proof of bias or market failures, other safety nets, rather than consumer protection regulation, is a more appropriate policy response with regard to group differences in relation to the compensatory potential of foreclosure. When considering policy responses, we should first investigate the characteristics of the specific consumers in the relevant sector and then identify the mechanisms that cause these consumers to be vulnerable (Fox O'Mahony et al. 2015, p. 114). I have investigated whether one aspect of the enforcement proceedings - appraiser bias - may explain the observed group differences in socio-economic status and found that it is likely not an explanation. Hence, I find no positive proof that motivates consumer protection policy aimed at the credit contract or its enforcement.

Additionally, we should consider that other possible explanatory factors are external to the foreclosure case, for example socio-economic group differences associated with purchasing price, property condition, or local house price depreciation. This indicates that a more appropriate policy response should target not only the interests of the credit contract parties and, consequently, further strengthens the argument that other safety nets should be considered. There may be certain free-rider problems, for example, if taxpayers bear the costs of negligent property maintenance. As long as redistribution of risk happens within the credit system, these problems are at least mitigated in relation to the welfare system. Therefore, I end this policy discussion with two such examples: one ex ante policy aimed at product design (shared-responsibility mortgages) and one ex post policy aimed at reducing over-indebtedness after foreclosure (debt relief).

Shared-responsibility mortgages, as advocated by Mian and Sufi (2015), is an exciting call for a shift in the entire structure of the industry for mortgage credit products towards "more equity-like contracts that are made contingent on risks outside the control of households" (p. 186). In essence, Mian and Sufi argue that mortgage credit as it exists today makes the borrower bear most of the risk for debt-driven home ownership and consumption. In a sharedresponsibility mortgage, the risk of arrears is instead shifted to a more even distribution between the lender and the borrower. This means that the borrower enjoys some protection through principal forgiveness in the event of falling house prices. The aim is to avoid foreclosure altogether. But in the case of foreclosure, the result is that arrears are lower. In return, the lender gets a share of rising house prices in the event of sale, voluntary or compulsory, or refinancing.

Debt relief after foreclosure sale also enables compensation since it may provide a "fresh start" (Ramsay 1997) by eliminating arrears. Sweden made debt relief possible in 1994. Since then, legal regulations have been changed repeatedly and the current Debt Relief Act (Swe. Skuldsaneringslag 2016) is from 2016. Nonetheless, at the core remains, the notion that all of the debtor's economic funds, in excess of funds required to provide a minimum economic standard of living, are allocated to paying the debts for a set time period, usually five years but now sometimes shorter. Only then is the debtor relieved of all non-collateral debt. Mortgage credit is always exempted up to the value of the house during debt relief, but this does not 
apply for arrears after the foreclosure sale. Accordingly, in the case of Sweden, it is possible to remedy low compensation during foreclosure by applying for debt relief. The result is that the risk of the mortgage contract is partially shifted to the borrower's other creditors, since they have to share the amount that the borrower should pay during debt relief with the mortgage lender (Ramsay 1997, p. 275). In this respect, Sweden may serve as an example for other jurisdictions to contemplate.

\section{Conclusion}

This study presents two main findings. Firstly, there is an association between the potential for compensation during foreclosure and borrower socio-economic status. Higher socio-economic status is positively correlated with greater potential for compensation. This is demonstrated in a multivariate OLS regression by the significant parameter estimates of the socio-economic variables income, higher education, and marriage. Secondly, the ratios between price and market value are quite similar for subgroups of high versus low socio-economic status. This indicates that appraiser bias is not likely to explain the association between socio-economic status and the compensatory potential of foreclosure.

Socio-economic group differences for borrowers in foreclosure attest to the need for consumer status and protection for this group of consumers. The absence of empirically demonstrated bias during enforcement proceedings indicates that appropriate policy remedies should target the redistribution of risk, not only between the lender and the borrower but also to other stakeholders through, for example, alternative mortgage products or debt relief. This study also contributes with an empirical description of foreclosure auctions in Sweden from 2000 to 2014. Conceptually, this study is intended as an empirical application of Donald Black's theories of law and compensation $(1976,1987)$. The results support the prediction that higher socio-economic status should be associated with more compensation.

Interesting areas for future empirical research would be to assess socio-economic group differences in relation to law's compensatory potential in other fields than foreclosure, and in other localities in time and space. There is also a need to shed more empirical light on why group differences occur to enlighten a fruitful legal policy discussion.

Availability of Data and Material Not applicable.

Authors' Contributions Not applicable.

Funding Open access funding provided by Lund University. This research study is part of the author's PhD project which is funded by the Swedish Enforcement Authority.

\section{Compliance with Ethical Standards}

Conflict of Interest The author is employed by the Swedish Enforcement Authority.

Ethical Approval This research study has been subject to ethical vetting at the Regional Board for Ethical Vetting in Lund (final decision 13 January 2016, dnr. 2015/763).

Code Availability Not applicable. 
Open Access This article is licensed under a Creative Commons Attribution 4.0 International License, which permits use, sharing, adaptation, distribution and reproduction in any medium or format, as long as you give appropriate credit to the original author(s) and the source, provide a link to the Creative Commons licence, and indicate if changes were made. The images or other third party material in this article are included in the article's Creative Commons licence, unless indicated otherwise in a credit line to the material. If material is not included in the article's Creative Commons licence and your intended use is not permitted by statutory regulation or exceeds the permitted use, you will need to obtain permission directly from the copyright holder. To view a copy of this licence, visit http://creativecommons.org/licenses/by/4.0/.

\section{References}

Acharya, V. V., \& Richardson, M. (2012). Implications of the Dodd-Frank act. Annual Review of Financial Economics, 4(1), 1-38.

Aldohni, A. (2017). The UK new regulatory framework of high-cost short-term credit: Is there a shift towards a more "law and society" based approach? Journal of Consumer Policy, 40(3), 321-345.

Bar-Gill, O., \& Ben-Shahar, O. (2013). Regulatory techniques in consumer protection: A critique of European consumer contract law. Common Market Law Review, 50(Special Issue), 109-125.

Bar-Gill, O., \& Warren, E. (2008). Making credit safer. University of Pennsylvania Law Review, 157(1), 1-101.

Been, V., Weselcouch, M., Voicu, I., \& Murff, S. (2013). Determinants of the incidence of US mortgage loan modifications. Journal of Banking \& Finance, 37(10), 3951-3973.

Black, D. (1976). The behavior of law (special edition 2010). Bingley: Emerald.

Black, D. (1984). Social control as a dependent variable. In D. Black (Ed.), Toward a general theory of social control, volume 1 (pp. 1-36). Orlando: Academic Press.

Black, D. (1987). Compensation and the social structure of misfortune. Law and Society Review, 21(4), $563-584$.

Bolåneutredningen. (2015). Stärkt konsumentskydd på bolånemarknaden (SOU 2015:40). Statens Offentliga Utredningar.

Chan, S., Sharygin, C., Been, V., \& Haughwout, A. (2014). Pathways after default: What happens to distressed mortgage borrowers and their homes? Journal of Real Estate Finance and Economics, 48(2), 342-379.

Cherednychenko, O. O. (2014). Freedom of contract in the post-crisis era: Quo vadis? European Review of Contract Law, 10(3), 390-421.

Cherednychenko, O. O., \& Meindertsma, J. M. (2019). Irresponsible lending in the post-crisis era: Is the EU consumer credit directive fit for its purpose? Journal of Consumer Policy, 42(4), 483-519.

Collins, J. M. (2014). Protecting mortgage borrowers through risk awareness: Evidence from variations in state laws. Journal of Consumer Affairs, 48(1), 124-146.

Collins, J. M., Schmeiser, M. D., \& Urban, C. (2013). Protecting minority homeowners: Race, foreclosure counseling and mortgage modifications. Journal of Consumer Affairs, 47(2), 289-310.

Collins, J. M., \& Urban, C. (2014). The dark side of sunshine: Regulatory oversight and status quo bias. Journal of Economic Behavior \& Organization, 107(part B), 470-486.

Cordell, L., \& Lambie-Hanson, L. (2016). A cost-benefit analysis of judicial foreclosure delay and a preliminary look at new mortgage servicing rules. Journal of Economics and Business, 84, 30-49.

Cowan, D. (2011). Housing law and policy. Cambridge: Cambridge University Press.

Davidson, N. M. (2013). New formalism in the aftermath of the housing crisis. Boston University Law Review, 93(2), 389-440.

De Gioia-Carabellese, P. (2018). The directive on the credit agreements for consumers relating to residential immovable property (directive 2014/17): A regulatory explanation and a private law analysis. European Business Law Review, 29(1), 33-57.

Dewar, M. R. T. (2013). Regulation X: A new direction for the regulation of mortgage servicers. The Emory Law Journal, 63(1), 175-220.

Domurath, I. (2013). The case for vulnerability as the normative standard in European consumer credit and mortgage law-An inquiry into the paradigms of consumer law. Journal of European Consumer and Market Law, 2(3), 124-137.

Domurath, I. (2015). A map of responsible lending and responsible borrowing in the EU and suggestions for a stronger legal framework to prevent over-indebtedness of European consumers. In H. Micklitz \& I. Domurath (Eds.), Consumer debt and social exclusion in Europe (pp. 155-175). London: Routledge.

Domurath, I. (2016). Mortgage debt and the social function of contract. European Law Journal, 22(6), 758-771. Donner, H. (2017). Foreclosures, returns, and buyer intentions. Journal of Real Estate Research, 39(2), 189-213. 
Donner, H. (2020). Determinants of a foreclosure discount. Journal of Housing and the Built Environment, 35 , 1079-1097.

Donner, H., Song, H., \& Wilhelmsson, M. (2016). Forced sales and their impact on real estate prices. Journal of Housing Economics, 34, 60-68.

European Banking Authority. (2015). Guidelines on arrears and foreclosure (EBA/GL/2015/12).

Esping-Andersen, G. (1990). The three worlds of welfare capitalism. Cambridge: Polity.

Ferretti, F. (2015). The over-indebtedness of European consumers: Time for a "fresh-start" of the EU policy and legal agenda? European Review of Contract Law, 11(4), 346-375.

Ford, J. (2012). Mortgage payment protection insurance. In S. J. Smith (Ed.), International encyclopedia of housing and home (7th ed., pp. 518-522). Amsterdam: Elsevier.

Ford, J., \& Quilgars, D. (2001). Failing home owners? The effectiveness of public and private safety-nets. Housing Studies, 16(2), 147-162.

Fox O’Mahony, L., Twigg-Flesner, C., \& Akinbami, F. (2015). Conceptualizing the consumer of financial services: A new approach? Journal of Consumer Policy, 38(2), 111-117.

Galanter, M. (1974). Why the "haves" come out ahead: Speculations on the limits of legal change. Law and Society Review, 9(1), 95-160.

Galobardes, B., Lynch, J., \& Smith, G. D. (2007). Measuring socioeconomic position in health research. British Medical Bulletin, 81-82, 21-37.

Garcia Porras, C. I., \& Van Boom, W. H. (2012). Information disclosure in the EU consumer credit directive: Opportunities and limitations. In J. Devenney \& M. Kenny (Eds.), Consumer credit, debt, and investment in Europe (pp. 21-55). Cambridge: Cambridge University Press.

Harris, R., \& Meir, A. (2015). Recourse structure of mortgages: A comparison between the US and Europe. CESifo DICE Report, 13(4), 15-22.

Lacko, J. M., \& Pappalardo, J. K. (2010). The failure and promise of mandated consumer mortgage disclosures: Evidence from qualitative interviews and a controlled experiment with mortgage borrowers. American Economic Review, 100(2), 516-521.

Levitin, A. J., \& Goodman, J. (2008). Mortgage market sensitivity to bankruptcy modification. 3rd Annual Conference on Empirical Legal Studies Papers. https://doi.org/10.2139/ssrn.1121054.

Mak, V. (2015). What is responsible lending? The EU consumer mortgage credit directive in the UK and the Netherlands. Journal of Consumer Policy, 38(4), 411-430.

Martin, E. (2016). Getting a second bite at the apple: The res judicata exception for seeking foreclosure deficiencies in Illinois. University of Illinois Law Review, 2016, 2271-2307.

Mian, A., \& Sufi, A. (2015). House of debt: How they (and you) caused the great recession, and how we can prevent it from happening again: With a new afterword. Chicago and London: University of Chicago Press.

Micklitz, H.-W. (2016). The consumer: Marketised, fragmentised, constitutionalised. In D. Leczykiewicz \& S. Weatherill (Eds.), The images of the consumer in EU law: Legislation, free movement and competition law (pp. 21-42). Oxford: Hart Publishing.

Mierzewski, M. B., DeSimone, B. S., Hochberg, J. W., \& Larkin, B. P. (2010). The Dodd-Frank act establishes the bureau of consumer financial protection as the primary regulatory of consumer financial products and services. Banking Law Journal, 127(8), 722-736.

Mierzewski, M. B., Hochberg, J. W., \& Landon, Q. (2013). CFPB finalizes new mortgage servicing rules. Banking Law Journal, 130(7), 599-610.

Nield, S. (2010). Responsible lending and borrowing: Whereto low-cost home ownership? Legal Studies, 30(4), 610-632.

Nield, S. (2015). Mortgage market review: "Hard-wired common sense?". Journal of Consumer Policy, 38(2), 139-159.

Oehler, A., \& Wendt, S. (2017). Good consumer information: The information paradigm at its (dead) end? Journal of Consumer Policy, 40(2), 179-191.

Persson, A. H., Henrikson, A.-S., \& Lundström, K. (2013). Household credit, indebtedness, and insolvency. European Review of Private Law, 21(3), 795-814.

Porter, K. (2008). Misbehavior and mistake in bankruptcy mortgage claims. Texas Law Review, 87(1), $121-182$.

Ramsay, I. (1997). Models of consumer bankruptcy: Implications for research and policy. Journal of Consumer Policy, 20(2), 269-287.

Ramsay, I. (2015). Two cheers for Europe: Austerity, mortgage foreclosures and personal insolvency policy in the EU. In: H. Micklitz \& I. Domurath (Eds.), Consumer debt and social exclusion in Europe (pp. 189-227). London: Routledge.

Ramsay, I. (2016). Changing policy paradigms of EU consumer credit and debt regulation. In D. Leczykiewicz \& S. Weatherill (Eds.), The images of the consumer in EU law: Legislation, free movement and competition law (pp. 159-182). Oxford: Hart Publishing.

Ramsay, I., \& Williams, T. (2020). Peering forward, 10 years after: International policy and consumer credit regulation. Journal of Consumer Policy, 43(1), 209-226. 
Squires, G. D., \& Hyra, D. S. (2010). Foreclosures-Yesterday, today, and tomorrow. City \& Community, 9(1), 50-60.

Stephens, M., \& Quilgars, D. (2007). Managing mortgage arrears and possessions in the UK. Housing Finance International, 21(5), 9-15.

Svallfors, S. (2004). Class, attitudes and the welfare state: Sweden in comparative perspective. Social Policy and Administration, 38(2), 119-138.

Voicu, I., Jacob, M., Rengert, K., \& Fang, I. (2012). Subprime loan default resolutions: Do they vary across mortgage products and borrower demographic groups? Journal of Real Estate Finance and Economics, 45(4), 939-964.

Wallace, A. (2012). 'Feels like I'm doing it on my own': Examining the synchronicity between policy responses and the circumstances and experiences of mortgage borrowers in arrears. Social Policy and Society, 11(1), $117-129$.

Wallace, A., \& Ford, J. (2010). Limiting possessions? Managing mortgage arrears in a new era. International Journal of Housing Policy, 10(2), 133-154.

Whitehouse, L. (1998). The home-owner: Citizen or consumer? In S. Bright \& J. Dewar (Eds.), Land law: Themes and perspectives (pp. 183-205). Oxford: Oxford University Press.

Whitehouse, L. (2015). The first legal mortgagor: A consumer without adequate protection? Journal of Consumer Policy, 38(2), 161-180.

Zhu, S., \& Pace, R. (2012). Distressed properties: Valuation bias and accuracy. Journal of Real Estate Finance and Economics, 44(1/2), 153-166.

\section{Legislation}

\section{European Union}

Directive 2008/48/EC on Credit Arrangements for Consumers

Directive 2014/17/EU on Credit Arrangements for Consumers relating to Residential Immovable Property

\section{Sweden}

Konsumentkreditlag (2010:1846)

Lag (1915:218) om avtal och andra rättshandlingar på förmögenhetsrättens område

Lag (1990:746) om betalningsföreläggande och handräckning

Lag (1936:81) om skuldebrev

Skuldsaneringslag (2016:675)

Utsökningsbalk (1981:774)

\section{USA}

Dodd-Frank Wall Street Reform and Consumer Protection Act of 2010, Public Law No. 111-203, 124 Stat. 1391 (2010)

Publisher's Note Springer Nature remains neutral with regard to jurisdictional claims in published maps and institutional affiliations. 